\title{
DYNAMIC MANAGEMENT OF OCCUPATIONAL HEALTH AND SAFETY PROCESSES IN INTEGRATED BUSINESS INFORMATION SYSTEMS
}

doi: $\quad 10.2478 /$ czoto-2019-0027

Date of submission of the article to the Editor: $07 / 12 / 2018$

Date of acceptance of the article by the Editor: 13/02/2018

Tomasz Turek ${ }^{1}$ - orcid id: 0000-0002-6946-6998

Paula Bajdor ${ }^{2}$ - orcid id: 0000-0002-5628-5952

${ }^{1}$ Czestochowa University of Technology, Poland, tomasz.turek@wz.pcz.pl

${ }^{2}$ Czestochowa University of Technology, Poland, paula.bajdor@wz.pcz.pl

\begin{abstract}
Currently operating enterprises are more and more willing to adopt a process approach in their structures. The process approach means the transition from traditionally understood management towards adapting to constantly changing environmental conditions. This change is accompanied by the possibility of using a wide range of tools of ICT technology, that allow modelling of any type of process occurring in the enterprise, including processes related to OHS. Thus, the objective of the paper is to indicate the opportunity for the integration of OHS processes with other processes (primary and auxiliary) of the organization using ERP systems. In the first part of the study, there will be indicated the determinants of the development of the process approach in modern enterprises. Subsequently, there will be characterized OHS processes against the background of other processes of the organization. In the third part, there will be indicated the most significant features of ERP systems. The last part will refer to the practical implementation of the process in the area of OHS in the Macrologic Merit system.
\end{abstract}

Keywords: management, process approach, Integrated Business Information System, occupational health and safety (OHS)

\section{INTRODUCTION}

Modern enterprises more and more frequently change the principles of operation and transform themselves into process organizations. This means that they depart from classic management taking into account rigid framework, structures and functions and they begin to consider the organization from the perspective of processes taking place in it. The development of the process approach is favored by an increasing role of information resources and the availability of ICT tools, including integrated IT systems for management. As a result, enterprises have more flexible and flattened structure (the so called horizontal organizations). Moreover, they faster and better respond to internal and external needs of organizations and contractors. Management in process enterprises becomes dynamic and integrated. It should be pinpointed that the 
enterprise cannot become a process organization in a moment. It is usually the course associated with reaching subsequent levels, the so called process maturity. In most cases, the identification and development of this approach relates to primary processes, which are directly connected with generating revenues by the enterprise (these are the so called primary processes), i.e. trade, services or production. Subsequently, there are taken into account auxiliary processes, which are activated somehow on the occasion of primary processes, e.g. administration, accounting etc. In modern enterprises, one, however, cannot forget about other processes without which it is impossible to operate properly and in accordance with the provisions, including the area of occupational health and safety (OHS). The OHS services must be provided obligatorily in enterprises employing more than 100 workers. Smaller entities can perform OHS tasks independently or benefit from external support. OHS tasks in process organizations must be taken into account in the process map. This requires proper identification, modeling and integration with the enterprise information system. Modern ERP systems facilitate these tasks.

\section{THE ESSENCE OF THE PROCESS APPROACH}

The process approach is the result of the occurrence of the concept of Business Process Reeingeering (BPR), which first perceived and placed the process in the center of attention of people responsible for proper enterprise management. The authors of this concept, M. Hammer and J. Champy, as early as in 1990s, claimed that the enterprises wishing to develop further, cannot operate according to old principles and in accordance with the previously adopted structures, instead, they should have the ability to adapt to dynamically changing conditions of the environment in which they operate (Hammer and Champy, 1996). Business Process Reengineering is fundamental rethinking from the beginning and thorough redesigning the processes taking place in the company aimed at a radical improvement in the results achieved, such as costs, quality, service and rapidity (Chang, 2006). The basic assumption of this concept is redesigning the organization and changing its functional system into the process system, indicating that the labor in modern enterprises should be focused on processes and not on single tasks, functions or jobs. The objective of this approach is to strive for optimizing the organizational structure of the enterprise while adopting its ability to generate customer value as a point of view (Grajewski, 2012). The process approach focuses on individual stages of actions, taken both inside and outside the enterprise, as well as the relationships between them in order to achieve the intended objective (Shendryk and Boiko, 2015). The adoption of the process approach by the enterprise requires the efficient management of processes, which are most often understood as appropriate development of relationships between individual elements in the enterprise at the stages of identifying, modeling, implementing and improving processes (Bitkowska, 2013). On the one hand, the enterprise applying the process approach is still characterized by the features typical of traditional functional structures, however, on the other, one can spot many differences, in the form of (Gorlenko and Mozhayeva, 2016):

- organization of activities around processes, and not around single tasks or the implementation of primary processes in the form of projects (e.g. in the case of the construction industry),

- improvements in processes, allowing the identification and elimination of unnecessary or excessive processes, 
- changes in the allocation of resources possessed so that individual processes are properly powered,

- creating the position of "a project manager", responsible for the course and implementation of processes as well as the creation of working teams serving individual processes,

- emphasizing team work and delegating powers to the operational level,

- carrying out performance measurements using the balanced scorecard or measurement of economic valuer added.

Nowadays, the versatility of this approach is manifested in its presence, among others, in the following management concepts:

- Total Quality Management (TQM), most of all, in quality systems compliant with the ISO 9000:2000 standards, in which there is a formal record on the use of the process approach: "so that the organization has the right process to identify and manage the activities for improvement in products, processes, quality and organization management system" (Brzozowski and Roagala 2017).

- Lean management, in which the process approach allows the identification of processes not creating any values.

- Efficiency Consumer Response (ECR) and Collaborative Planning, Forecasting and Replenishment, in which there is integration of actions occurring in supply chains. The use of the process approach prevents the occurrence of "a bullwhip effect", which effect is the inherent increase in demand fluctuation up the supply chain. Managing the bullwhip effect is minimizing the fluctuation and variation of the demand throughout the supply chain (Wilck, 2018).

- Knowledge management, consisting of six major processes: knowledge identification, acquisition, development, sharing, utilization and retention (Probst and Romhartd, 2002).

- Marketing, which, due to the use of this approach, is evolving towards partnership marketing (Fonfara, 2004).

Moreover, the process approach binds together three important areas: information and knowledge management (Perechuda, 2005), quality management (Luburic et al., 2015) and performance management (Kaplan and Norton, 2001), which are the components of modern enterprise management models. Nowadays, the process approach is one of the most important and most extensively used concepts in enterprise management, also treated as one of paradigms of modern management of organizations, affecting the operation of the entire company.

\section{THE PLACE OF THE OHS PROCESSES IN MODERN ENTERPRISES}

The activity of modern enterprises is supported by different types of systemic solutions, applied in the area of management. The areas, which are being currently emphasized, most of all, are, among others, quality, concern for the natural environment or occupational safety. In order to satisfy increasingly rigorous requirements relating to occupational safety, occupational health and safety systems are more and more often implemented in enterprises. The main and, at the same time, basic document regulating the issues of occupational health and safety is the OHSAS 18001:2007 standard, on the basis of which the OHS system is defined as the complex whole composed of resources, policy, procedures and employees that operate in an organized manner and their objective is to realize specific tasks 
(Model..., 2018). The main components of the OHS system in Polish enterprises are, most of all, (Klimecka-Tatar and Ulewicz, 2015):

- commitment of management, clearly defined security policy and active participation of employees,

- planning activities including the establishment of general and specific objectives, establishing the plans for their fulfillment and running processes of risk assessment.

Moreover, this system assumes constant improvement, which is possible due to the process approach applied in the enterprise. Admittedly, the processes associated with OHS do not create value added but they contribute to the efficient operation of the enterprise and allow the fulfillment of increasingly rigorous legal requirements in the field of OHS. The process of management of occupational health and safety can be defined as: the sequence of operations following each other, implemented in the enterprise in order to ensure safety of all employees and protection of their health at the workplace (Pacana, 2016). The essence of this process is presented in Figure 1.

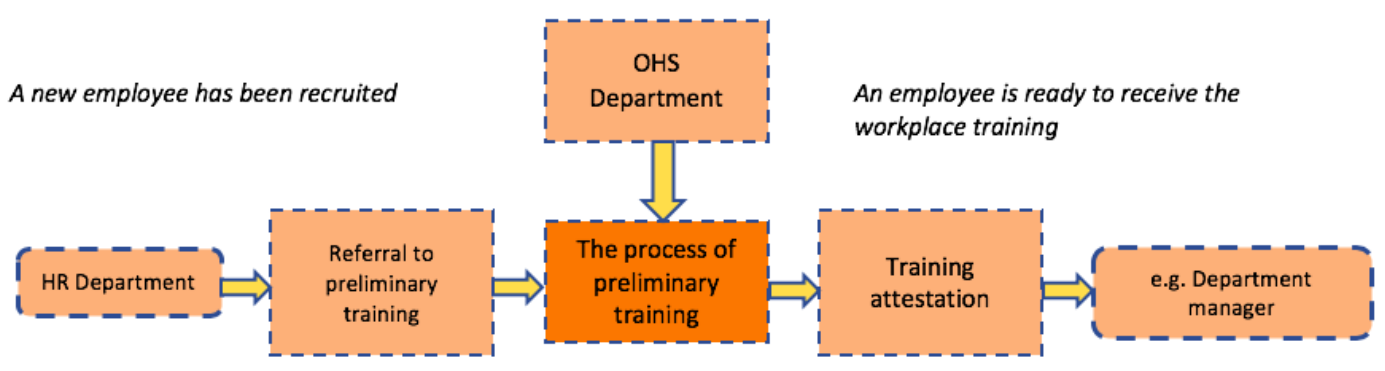

Fig. 1. An example of the process approach in OHS

As indicated by the presented figure, in this process, the participant (in this case, a newly recruited employee) of one process is simultaneously the output of one process and the input of another process.

However, regardless of the size and industry in which the company operates or risks occurring in it, in each economic entity, it is possible to identify some constant processes associated with OHS:

- the process of occupational risk assessment,

- the process of monitoring of working conditions,

- the process of corrective/preventive actions,

- the process of OHS training,

- the process of internal communication concerning OHS,

- the process of identification and implementation of legal requirements concerning OHS in force into the enterprise operations.

The processes listed above are inscribed into the PDCA cycle developed by E. Deming, which becomes the common element for management of occupational health and safety and the process approach. It illustrates process management in relation to the tasks performed and the implementation of processes (Fig. 2). 


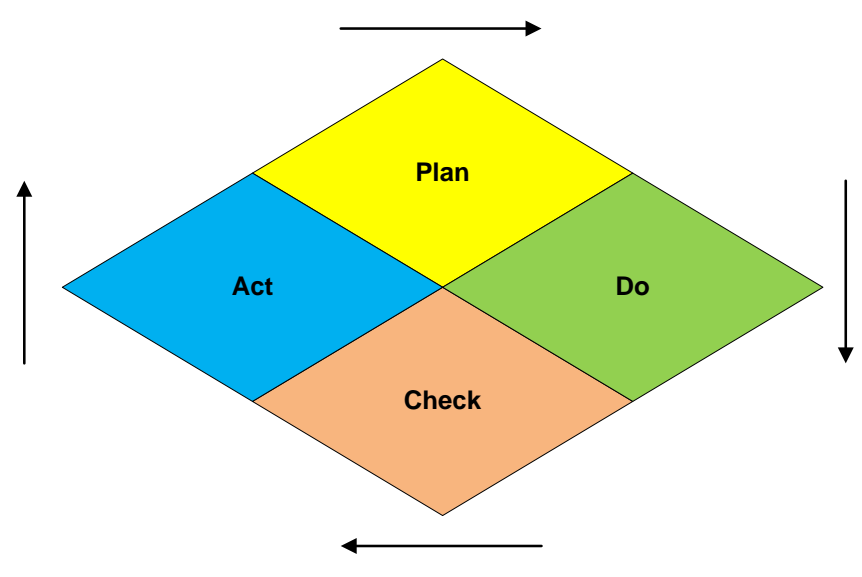

Fig. 2. PDCA Deming's cycle

The cycle includes four stages:

1. Plan - planning what the enterprise wants to achieve through its actions,

2. Do - implementing the actions planned,

3. Check - verifying the tasks performed,

4. Act - improving, streamlining in order to achieve better results.

The essence of the process approach in OHS is manifested with the fact that the processes taking place in this area run in accordance with the PDCA cycle, in which the output of each stage automatically becomes the input of another stage. Having in mind that the main objective of OHS in the enterprise is to minimize or totally eliminate the occurring risk/threats accompanying the work performed, it can be assumed that only the process approach, assuming striving for effective work, minimizing risk and increasing the level of quality, enables the achievement of this objective. It should also be borne in mind that the processes running in the area of $\mathrm{OHS}$ also affect other areas of the enterprise activity, which brings about that there is their integration with other processes taking place in the enterprise, which will be presented in the following part of the study.

\section{PROCESS MANAGEMENT IT SYSTEMS}

The development of the concept of the process approach has been affected by the increasingly common use of IT systems by enterprises since, as pointed by T.H. Davenport, this is "software that enforces the process orientation" (Cieśliński, 2009) and the activity and further development of the enterprise would not be possible nowadays without using IT systems, at least to a small extent.

The practical implementation of the process approach in IT systems, most of all, takes place through ERP solutions. Modern ERP systems include all the key areas of the organization (Human Resources, Wages, Production, Logistics, Finance, Accounting etc.). The development of modern ICT and Cloud Computing solutions also allows the multidimensional cooperation at the level of business processes between cooperators and even in cooperation networks. In this case, the ERP 2.0 and 3.0 systems are related to. Not all IT systems allow the dynamic process management since some of them are merely a set of functions, commands and procedures which have been subjected to digitization and are supported with IT. Another group is ERP systems which, due to the lack of tools for modeling and mapping, do not allow for full process management. Information resources and documents are indeed linked in 
a logical whole in them but they do not constitute the process in the full sense. They are not formalized and do not have models. Increasingly, however, there arise ERP systems, allowing for dynamic process management. They include integrated modeling tools and the processes designed develop the way of process implementation and achievement of objectives. Therefore, in practice, the following ERP systems can be identified: non-process, quasi-process and strictly process (See more: Nekrasenko, Cymanow, Turek 2018). Dynamic process management in the integrated management IT systems means therefore the possibility of identification, formalization and modeling of processes. Moreover, the models of business processes enforce the way of their implementation and allow the measurement and analysis of the course of individual stages of processes. An example of the strictly process ERP is the Macrologic Xpertis system. It includes the pre-defined list of business processes which are most common in enterprises (over 200 process models). As a result, the implementation of the system can take place in a flexible manner. The enterprise uses ready-made models or creates its own models, adapted to the specificity and needs.

\section{AN EXAMPLE OF THE INTEGRATION OF THE OHS PROCESS WITH OTHER PROCESSES OF THE ORGANIZATION}

Although ERP systems include all the key functional areas of enterprises, the OHS aspects are often omitted in them or they are of marginal importance. For instance, a very popular Comarch Optima system brings the OHS aspects to the registration of OSP training sessions, periodic inspections and qualifications of employees in the HR module. Another example is the TETA ERP system. In the TETA HR module, it is possible to register OHS services for the benefit of employees. Also, the aforementioned Macrologic Merit system relates to OHS only within the framework of activities in the field of human resources. This activity is the review and registration of training sessions in OHS and fire-fighting. However, Macrologic Merit is a strictly process system. It allows dynamic process management. The list of processes is not limited and closed in it. In a situation where the needs and specificity of the enterprise need to add the support for a new process one may use the process modeler (e.g. in order to create the process of issuing work wear to workers) - Figure $3^{1}$.

New Process Model - New Process Model (wersja: VER 1)

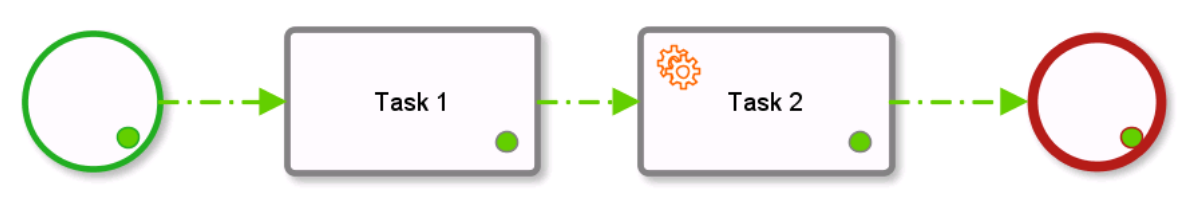

Fig. 3. Macrologic Merit Process Modeler

The created process of issuing work wear to workers must include the primary data, among others: the symbol, name, owner and purpose. The created and approved process model (Fig. 4) is permanently included in the list of processes (Fig. 5) and is available for all the authorized users of the IT system.

\footnotetext{
${ }^{1}$ Macrologic Mmerit is not translated into English yet
} 
BHP_ROB - Issuance of workwear to an employee (wersja: 17.42)

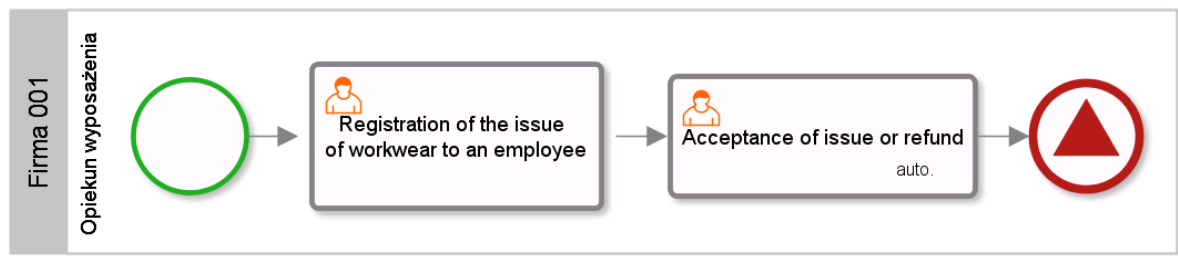

Fig. 4. Model of Issuance of workwear to an employee

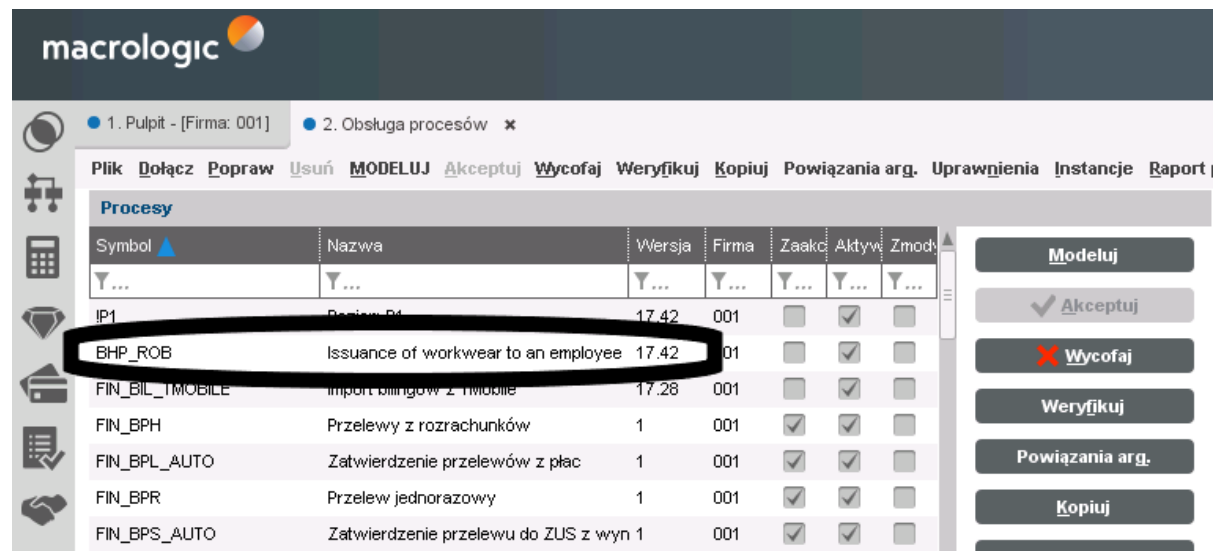

Fig. 5. List of processes (new process added)

In this way, it is possible to create the whole set of processes concerning OHS and their integration with other processes in the ERP system.

\section{CONCLUSIONS}

ERP systems have been associated exclusively with large enterprises for years. The changes in the market of integrated management IT systems, reduction in prices, hardware requirements and general development of ICT (Information and Communication Technology) caused, however, that the systems of this class are currently commonly used in small and medium organizations. ERP systems are universal solutions supporting the key areas of the company. In the paper, the attention has been drawn to the fact that the area of OHS is not sufficiently supported by the systems of this class. Most of them allow only the implementation of primary tasks and processes.

The situation in the process IT systems is different. In the case of the lack of support for the required processes (including OHS processes), it is possible to add them to the system. For this purpose, a special process modeler is applied (most often compliant with BPM). Adding a new process provides an opportunity not only for activation but also a thorough analysis of individual stages of the process. Thus, the authorized managers and analysts receive broad spectrum of information on the course of the process, time of implementation, bottlenecks in the organization, failure in the start or the end of the process.

Dynamic process management in strictly process ERP systems contributes to flexible management of the enterprise using the IT system since the system is not the barrier to management but an important link supporting the operation of the organization. 


\section{REFERENCES}

Bitkowska, A., 2013. Zarządzanie procesowe we współczesnych organizacjach, Difin, Warszawa.

Brzozowski, T., Rogala, P., 2017. Podejście procesowe według norm ISO serii 9000 Istota i ewolucja, Prace naukowe Uniwersytety ekonomicznego we Wrocławiu, Biznes i środowisko - wybrane problemy, 470, 19-28.

Chang, J.F., 2006. Business Process Management Systems. Strategy and Implementation, Auerbach Publications, New York.

Cieśliński, W., 2009. Procesowa orientacja przedsiębiorstw - wyniki badań empirycznych, [in:] S. Nowosielski (ed.), Podejście procesowe w organizacjach, Wydawnictwo Uniwersytety Ekonomicznego we Wrocławiu, Wrocław, 41-48.

Fonfara K., 2004. Marketing partnerski na rynku przedsiębiorstw, Polskie Wydawnictwo Ekonomiczne, Warszawa.

Gorlenko, O., Mozhayeva, T., 2016. The Process Approach to Management of Enterprise Human Resources, Materials Science and Engineering, 124, 1-6.

Grajewski, P., 2012. Procesowe zarządzanie organizacją, Polskie Wydawnictwo Ekonomiczne, Warszawa.

Hammer, M., Champy, J., 1996. Reengineering w przedsiębiorstwie, Neumann Management Institute, Warszawa.

Kaplan, R.S., Norton, D.P., 2001. Strategiczna karta wyników. Jak przełożyć strategię na działania, Polskie Wydawnictwo Naukowe, Warszawa.

Klimecka-Tatar, D., Ulewicz, R., 2015. Bezpieczeństwo na stanowisku pracy w aspekcie zintegrowanych systemów zarządzania, [in:] T. Nitkiewicz, W. Jędrzejczyk (eds.), Zarządzanie BHP - czynniki oddziaływania na stanowisko i środowisko pracy, Wydawnictwo Wydziału Zarządzania Politechniki Częstochowskiej, Częstochowa, 11-22.

Luburic, R., Perovic, M., Sekulovic, R., 2015. Quality Management in Terms of Strengthening the "Three Lines to Defence" in Risk Management - Process Approach, International Journal for Quality Research, 9(2), 243-250.

Model systemu zarządzania BHP wg polskich norm serii PN-N-18000, available on http://archiwum.ciop.pl/11886.html (accessed on 11-12-2018).

Nekrasenko L. Cymanow P., Turek T., 2018, IT Alternative in Economic System Development, Wydawnictwo Wydziału Zarządzania Politechniki Częstochowskiej, Częstochowa.

Pacana, A., 2016. Synteza systemowego zarządzania bezpieczeństwem i higieną pracy, Oficyna Wydawnicza Politechniki Rzeszowskiej, Rzeszów.

Perechuda K., 2005. Dyfuzja wiedzy w przedsiębiorstwie sieciowym, Wizualizacja i kompozycja, Akademia Ekonomiczna we Wrocławiu, Wrocław 2005.

Probst, G., Romhardt, K., 2002. Building Blocks of Knowledge Management A Practical Approach, Ecole des Hautes Etudes Commerciales, Universite de Geneve.

Shendryk, V., Boiko, A., 2015. Stages of information system development In the process approach, Procedia Computer Science, 77, 98-103.

Wilck, J.H., 2018. Managing the Bullwhip Effect, United States Air Force Academy, available on https://www.researchgate.net/publication/267997664_MANAGING_T HE_BULLWHIP_EFFECT, accessed on 11-12-2018) 